\title{
KARAKTERISASI PATOGEN, INANG SPESIFIK, DAN SEBARAN MYCOBACTERIOSIS
}

\author{
Hambali Supriyadi, Pipik Taupik, dan Taukhid
}

\begin{abstract}
ABSTRAK
Penelitian ini bertujuan untuk mengetahui karakteristik penyebab penyakit jenis-jenis ikan yang terinfeksi serta daerah sebar dari penyakit mycobacteriosis. Penelitian ini dilakukan di beberapa kabupaten di Provinsi Jawa Barat, Banten, DKI Jakarta, Jawa Tengah, Daerah Istimewa Yogyakarta, dan Jawa Timur. Ikan sampel adalah jeris-jenis ikan yang dibudidayakan. Isolat diambil dari ginjal dan bagian-bagian yang menunjukkan adanya gejala infeksi, kemudian ditanam di atas media Shauton dan diidentifikasi dengan penelusuran karakter bentuk, fisik, dan biokimia. Hasil penelitian menunjukkan bahwa Mycobacterium fortuitum merupakan jasad penyebab mycobacteriosis, dengan inang yang dapat terinfeksi meliputi ikan mas (Cyprinus carpio), ikan nila (Oreochromis niloticus), dan ikan gurami (Osphronemus gouramy), sedangkan sebarannya meliputi Jawa Barat, Banten, DKI Jakarta, Jawa Tengah, Daerah Istimewa Yogyakarta: dan Jawa Timur.
\end{abstract}

\begin{abstract}
Characterization of the pathogen, susceptible host, and distribution of my. cobacteriosis. By: Hambali Supriyadi, Pipik Taupik, and Taukhid

The aims of this research were to identify characters of the pathogen and to gain the information on the susceptible host and distribution of mycobacteriosis. The research was conducted in West Java, Banten, Jakarta, Central Java, Yogyakarta, and East Java Provinces. Isolates were taken from kidney and organs which indicated clinical sign, then isolated onto Shauton's me. dium. Identification was done based on the bacterial shape, physical and biochemical characters. The results indicated that Mycobacterium fortuitum was the causative agent of disease and common carp (Cyprinus carpio), nile tilapia (Oreochromis niloticus) and giant gouramy (Osphronemus gouramy) were the susceptible hosts, while the distribution of diseases covered West Java, Banten, Jakarta, Central Java, Yogyakarta, and Easi Java Provinces.
\end{abstract}

KEYWORDS: characters, susceptible host, distribution, mycobacteriosis

\section{PENDAHULUAN}

Penyakit bakterial merupakan salah satu masalah serius yang selalu dihadapi oleh petani ikan karena penyakit tersebut selain dapat mengakibatkan kematian sekitar 50\%--100\% (Supriyadi \& Taufik, 1981; Taufik, 1992; Supriyadi \& Rukyani, 1990), juga dapat menurunkan mutu daging dari ikan yang terinfeksi berupa borok atau luka, sehingga tidak disukai oleh konsumen.

Penyakit bakterial yang disebabkan oleh bakteri Mycobacterium sp. terutama pada ikan konsumsi dan ikan hias telah banyak dilaporkan (Nigrelli \& Vogel, 1963; Chinabut et al., 1990). Penyakit tersebut dapat menimbulkan kematian lebih dari $20 \%$ pada ikan gabus (Limsuwan et al., 1983) dan menurunkan mutu ikan itu sendiri. Gejala klinis infeksi bakteri tersebut seperti mata menonjol (exopthalmos), adanya benjolan pada tubuh, dan terdapatnya bintik-bintik putih (tubercle) pada ginjal, hati, dan limpa telah terihat pada ikan gurami. Penyakit tersebut di indo. nesia telah banyak dilaporkan dan cukup menimbulkan kerugian yang berupa kematian dan penurunan mutu ikan. Mycobacteriosis atau sering juga disebut dengan tuberculosis pada ikan merupakan penyakit yang kronik dan dapat menginfeksi berbagai spesies ikan air laut dan ikan air tawar serta dilaporkan lebih dari 150 spesies ikan dapat terinfeksi penyakit tersebut (Frerichs, 1993). Chinabut et al. (1990) melaporkan lebih dari 151 spesies ikan air laut dan air tawar dapat terinfeksi mycobacteriosis, terutama ikan gabus (Channa striatus) dan cupang (Betta splendens). Spesies bakteri yang sering menginfeksi ikan adalah Mycobacterium marinum, $M$. fortuitum, dan $M$. chelonei.

Supriyadi (1999) teiah mengidentifikasi bakteri Mycobacterium fortuitum dari ikan gurami (Osphronemus gouramy) dan ternyata bahwa dari 350 sampel yang diperoleh dari kolam-kolam di Ciasem $60,3 \%$ terinfeksi mycobacteriosis. Sedangkan sampel

Peneliti pada Balai Riset Perikanan Budidaya Air Tawar, Bogor 
ikan yang diperoleh dari Parung ternyata 36\% terinfeksi mycobacteriosis.

Berdasarkan pada tingkat bahaya yang dapat ditimbulkan oleh penyakit ini maka sangat penting untuk diketahui tentang cara penanggulangannya. Oleh karena itu harus segera diketahui tentang halhal mendasar mengenai penyakit ini antara lain tentang 1) karakter dari jasad penyebab penyakit agar dapat menentukan jenis obat yang tepat bag pengobatannya, 2) inang yang dapat diinfeksi, sehingga dapat dilakukan pemilihan spesies ikan yang tepat untuk dibudidayakan pada tempat yang telah terinfeksi oleh penyakit tersebut, dan 3) sebaran penyakit tersebut sehingga dapat segera diadakan pembatasan penyebarannya.

\section{BAHAN DAN METODE}

\section{Ikan Sampel}

Ikan sampel terdiri atas jenis-jenis ikan yang dibudidayakan di daerah yang disurvai yaitu ikan mas, ikan nila, ikan gurami, dan ikan lele. Sampel ikan diambil secara acak (tidak dipilih) sebanyak 10--20 ekor untuk tiap spesies ikan yang dibudidayakan.

\section{Lokasi Survai}

Adapun daerah yang disurvai adalah: Provinsi Banten meliputi 2 kabupaten yaitu Kabupaten Serang dan Kabupaten Pandeglang; DKI Jakarta meliputi Kota Jakarta Timur dan Kota Jakarta Selatan; Jawa Barat meliputi 4 kabupaten yaitu Kabupaten Tasikmalaya, Kabupaten Bandung, Kabupaten Cianjur, dan Kabupaten Sukabumi; Jawa Tengah meliputi 3 kabupaten yaitu Kabupaten Purbalingga, Kabupaten Banyumas, dan Kabupaten Cilacap; Daerah Istimewa Yogyakarta meliputi 2 kabupaten yaitu Kabupaten Sleman dan Kabupaten Bantul; Jawa Timur meliputi 4 kabupaten yaitu Kabupaten Malang, Kabupaten Blitar, Kabupaten Tulung Agung, dan Kabupaten Madiun. Untuk tiap kabupaten sampel diambil dari 2 (dua) kecamatan yang berbeda.

\section{Isolasi dan Karakterisasi}

Media bakteri yang dipakai adalah media selektif untuk genus Mycobacterium yaitu media Shouton. Isolat diambil dari ginjal bagian depan, dan bagi ikan yang menunjukkan gejala infeksi maka isolat juga diambil dari luka kulit, mata, dan dari organ yang menunjukkan adanya granuloma. Isolat yang diambil kemudian ditanam di atas media Shouton dan diinkubasikan pada suhu $28^{\circ} \mathrm{C}$ selama $7--15$ hari.

Identifikasi dilakukan dengan menggunakan metode identifikasi konvensional yang berdasar pada karakter morfologi dengan pengecatan Ziehl-Neelsen (ZN), fisik, dan biokimia sesuai dengan metode yang dikemukakan Amos (1985), Cowan (1985), dan Frerich \& Millar (1993).

Derajat insidensi (DI)/prevalensi penyakit tersebut pada masing-masing grup ikan sampel yang diambil dari berbagai derah pengambilan sampel dihitung dengan rumus:

$$
\mathrm{DI}=\frac{\text { Jumlah ikan yang terinfeksi }}{\text { Jumlah sampel yang diperiksa }} \times 100 \%
$$

\section{HASIL DAN BAHASAN}

Dari hasil penelusuran terhadap karakter baik bentuk, fisik, maupun biokimia ternyata bahwa jasad patogen tumbuh pada medium Shauton, tercat oleh pengecatan "Acid Fast/Zeihl Nelson", berbentuk batang, tumbuh pada suhu $37^{\circ} \mathrm{C}$. Bakteri tersebut juga tumbuh pada MacConkey agar, dapat mereduksi nitrat, dan mampu memetabolis sukrosa. Oleh karena itu berdasarkan pada karakter tersebut maka bakteri penyebab mycobacteriosis adalah Mycobacterium fortuitum. Tidak satu pun dari isolat yang diperoleh menunjukkan karakter untuk spesies lain seperti $M$. marinum dan $M$. chelonae.

Gejala klinis yang ditunjukkan adalah adanya benjolan pada tubuh dan mata menonjol. Kalau ikan tersebut dibedah maka akan terlihat adanya granuloma pada hati, limfa, ginjal, dan daging ikan seperti terlihat pada Gambar 1.

Di Provinsi Jawa Barat ternyata infeksi mycobacteriosis sudah ditemukan pada jenis-jenis ikan utama yang dibudidayakan (Tabel 1) yaitu antara lain ikan mas (Cyprinus carpio), nila (Oreochromis niloticus), dan gurami (Osphronemus gouramy), dengan prevalensi serangan cukup tinggi. Sedangkan di Provinsi Banten (Tabel 2), prevalensi infeksinya masih rendah. Hal serupa juga ditemukan di Daerah Khusus Ibukota Jakarta (Tabel 3).

Prevalensi infeksi mycobacteriosis cukup tinggi ditemukan di Provinși Daerah Tingkat I Jawa Tengah (Tabel 4) yang diwakili oleh beberapa kabupaten yaitu Banyumas, Cilacap, dan Purbalingga yaitu pada ikan nila dan ikan gurami. Demikian juga di Daerah Istimewa Yogyakarta pervalensi infeksi mycobacteriosis ini sudah mulai meningkat terutama di daerah yang membudidayakan ikan gurami (Tabel 5). Sedangkan di Provinsi Jawa Timur (Tabel 6), prevalensi infeksi penyakit ini masih cukup rendah.

Prevalensi infeksi mycobacteriosis pada ikan mas (Cyprinus carpio) dan nila (Oreochromis niloticus) yang 


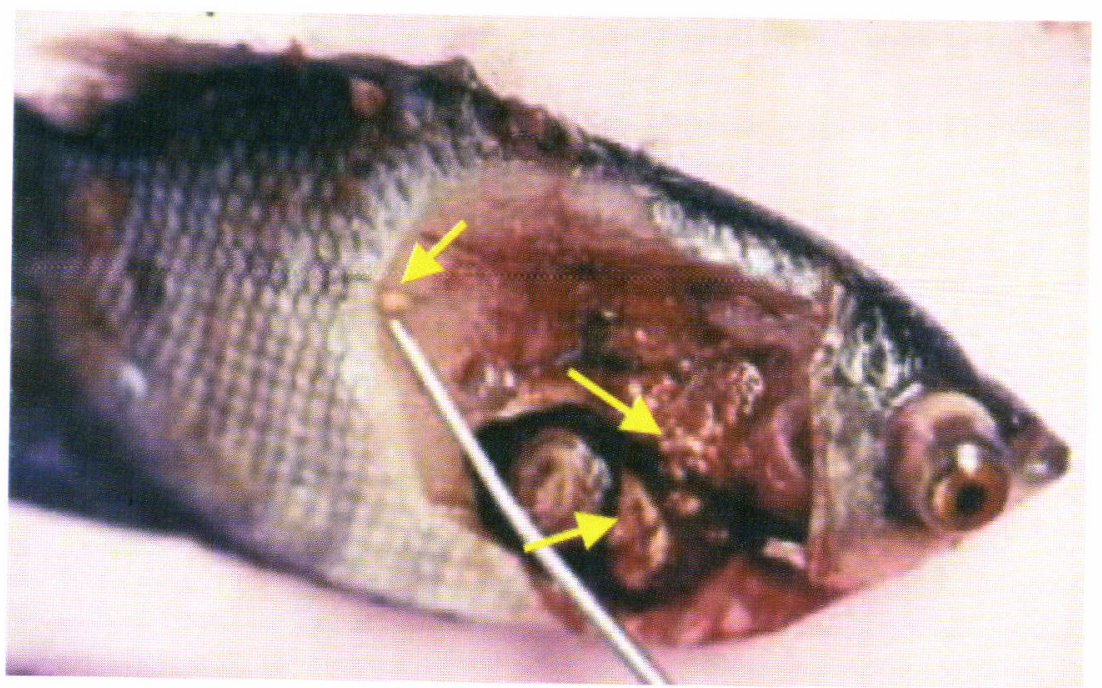

Gambar 1. Granuloma yang terdapat pada ginjal, hati, dan daging ikan gurami (tanda panah) yang terinfeksi mycobacteriosis

Figure 1. Granulomas in kidney, liver, and muscel (arrow) of gouramy infected by mycobacteriosis

Tabel 1. Prevalensi (\%) dan spesies yang rentan terhadap infeksi mycobacteriosis pada beberapa kebupaten di Provinsi Jawa Barat

Table 1. Prevalence (\%) and the susceptable species to the infection of mycobacteriosis In West Java Province

\begin{tabular}{llc}
\hline $\begin{array}{c}\text { Jenis ikan } \\
\text { Species of fish }\end{array}$ & \multicolumn{1}{c}{$\begin{array}{c}\text { Lokasi } \\
\text { Location }\end{array}$} & $\begin{array}{c}\text { Prevalensi (\%) } \\
\text { Prevalence }\end{array}$ \\
\hline Mas (Cyprinus carpio) & Sukabumi 1 & 80 \\
& Sukabumi 2 & 40 \\
& Cianjur 2 & 50 \\
\hline Nila (Oreochromis niloticus) & Tasikmalaya 1 & 0 \\
& Tasikmalaya 2 & 50 \\
& Sukabumi 1 & 10 \\
& Sukabumi 2 & 30 \\
& Bandung & 30 \\
\hline Gurami (Osphronemus gouramy) & Tasikmalaya 1 & 60 \\
& Tasikmalaya 2 & 20 \\
& Sukabumi 1 & 50 \\
& Cianjur 1 & 40 \\
\hline
\end{tabular}

secara intensif telah dikembangkan baik pada sistem budi daya kolam (misalnya Sukabumi) maupun jaring apung (Cianjur) di Provinsi Jawa Barat ternyata cukup tinggi. Hal ini dapat dilihat apabila dibandingkan dengan insidensi/prevalensi infeksi mycobacteriosis di Provinsi Banten (Tabel 2), di mana sistem budi dayanya masih bersifat ekstensif tradisional. Kolamkolam yang digunakan masih berupa kolam tanah dengan kepadatan yang cukup rendah yaitu untuk nila antara 5--30 ekor $/ \mathrm{m}^{3}$ dan untuk ikan mas 10-- 15 ekor/ $\mathrm{m}^{3}$. Namun demikian, ikan gurami di Kabupaten Pandeglang yang telah mulai dilaksanakan dengan sistem monokultur ternyata memiliki prevalensi infeksi mycobacteriosis yang relatif cukup tinggi (20\%).

Di Daerah Khusus Ibukota (DKI) Jakarta aktivitas budi daya lebih banyak pada ikan hias. Namun demikian masih ada beberapa daerah di DKI Jakarta yang membudidayakan ikan konsumsi seperti halnya Kota Jakarta Selatan dan Jakarta Timur. Di Jakarta Selatan, aktivitas budi daya ikan didominasi oleh ikan hias dan gurami. Namun infeksi mycobacteriosis dari daerah tersebut tidak ditemukan. Sedangkan prevalensi infeksi mycobacteriosis pada ikan gurami di Jakarta Timur cukup tinggi. 
Tabel 2. Prevalensi (\%) dan spesies yang rentan terhadap infeksi mycobacteriosis pada beberapa kabupaten di Provinsi Banten

Table 2. Prevalence (\%) and the susceptable species to the infection of mycobacteriosis in Banten Province

\begin{tabular}{llc}
\hline $\begin{array}{c}\text { Jenis ikan } \\
\text { Species of fish }\end{array}$ & \multicolumn{1}{c}{$\begin{array}{c}\text { Lokasi } \\
\text { Location }\end{array}$} & $\begin{array}{c}\text { Prevalensi (\%) } \\
\text { Prevalence }\end{array}$ \\
\hline Mas (Cyprinus carpio) & Serang 1 & 10 \\
& Serang 2 & 10 \\
& Pandeglang 2 & 0 \\
\hline Nila (Oreochromis niloticus) & Serang 1 & 15 \\
& Serang 2 & 15 \\
& Pandeglang 3 & 10 \\
\hline Gurami (Osphronemus gouramy) & Pandeglang 1 & 20 \\
\hline
\end{tabular}

Infeksi mycobacteriosis pada ikan cupang (Betta splendens) tidak ditemukan pada sampel yang diperoleh dari Jakarta, padahal ikan tersebut menurut Somsiri \& Sukrakanchana (1997), merupakan spesies ikan yang sering terinfeksi oleh penyakit ini. Hal ini mungkin karena pola manajemen budi daya yang diterapkan sudah sempurna sehingga tidak memungkinkan bagi penyakit tersebut untuk menginfeksi lokasi tersebut.

Budi daya ikan nila (Oreochromis niloticus) dan ikan gurami (Osphronemus gouramy) di beberapa kabupaten di Jawa Tengah seperti Kabupaten Banyumas, Purbalingga, dan Cilacap telah berkembang dengan pesat. Perkembangan tersebut kelihatannya telah mengakibatkan sering timbulnya kasus infeksi beberapa penyakit ikan. Hal ini antara lain dapat dilihat dari prevalensi penyakit mycobacteriosis yang cukup tinggi pada ikan yang dibudidayakan di daerah tersebut (Tabel 4). Bahkan kalau dibandingkan dengan beberapa daerah yang diamati di Pulau Jawa, daerah tersebut menunjukkan daerah yang memiliki prevalensi infeksi mycobacteriosis yang tertinggi baik pada ikan nila maupun pada ikan gurami. Hal ini diduga karena perkembangan budi daya ikan di daerah tersebut tidak diikuti dengan pola manajemen budi daya dan manajemen lingkungan yang baik.

Walaupun perkembangan budi daya ikan di Daerah Istimewa Yogyakarta belum maju apabila dibandingkan dengan daerah lain terutama pada taraf petaninya ternyata penyakit mycobacteriosis telah pula menginfeksi daerah ini (Tabel 5). Dari beberapa sampel ikan yang diambil baik dari petani maupun dari Balai Benih Ikan menunjukkan bahwa di daerah tersebut sudah ada penyakit mycobacteriosis yang prevalensinya sudah cukup tinggi terutama pada ikan gurami $(87,5 \%)$ yang berasal dari Jetak, Kelurahan Sendang Tirto, Kecamatan Brebah, Kabupaten Sleman.

Kolam-kolam di tempat tersebut berupa kolam tanah dengan luasan yang sempit $\left(3 \times 3 \mathrm{~m}^{2}\right)$, sumber air yang digunakan berasal dari saluran irigasi, dengan kedalaman air sekitar $60 \mathrm{~cm}$. Sistem budi daya yang diterapkan adalah tradisional dengan pakan campuran pelet dan roti afkir.

Sumber infeksi diduga berasal dari sumber air yang digunakan yaitu air yang berasal dari saluran irigasi. Menurut informasi dari pemilik, benih diproduksi sendiri dari induk-induk yang dimilikinya. Jadi sedikit

Tabel 3. Prevalensi (\%) dan spesies yang rentan terhadap infeksi mycobacteriosis di beberapa Kota Daerah Khusus Ibukota Jakarta

Table 3. Prevalence (\%) and the susceptable species to the infection of mycobacteriosis in Jakarta

\begin{tabular}{llc}
\hline $\begin{array}{c}\text { Jenis ikan } \\
\text { Species of fish }\end{array}$ & \multicolumn{1}{c}{$\begin{array}{c}\text { Lokasi } \\
\text { Location }\end{array}$} & $\begin{array}{c}\text { Prevalensi (\%) } \\
\text { Prevalence }\end{array}$ \\
\hline Gurami (Osphronemus gouramy) & $\begin{array}{l}\text { Jakarta Selatan } \\
\text { Jakarta Timur }\end{array}$ & 0 \\
\hline Cupang (Betta splenden) & Jakarta Selatan & 0 \\
\hline Belida (Notopterus sp.) & Jakarta Timur & 0 \\
\hline
\end{tabular}


Tabel 4. Prevalensi (\%) dan spesies yang rentan terhadap infeksi mycobacteriosis pada beberapa kabupaten di Provinsi Jawa Tengah

Table 4. Prevalence (\%) and the susceptable species to the infection of mycobacteriosis in Central Java Province

\begin{tabular}{clc}
\hline $\begin{array}{c}\text { Jenis ikan } \\
\text { Species of fish }\end{array}$ & \multicolumn{1}{c}{$\begin{array}{c}\text { Lokasi } \\
\text { Location }\end{array}$} & $\begin{array}{c}\text { Prevalensi (\%) } \\
\text { Prevalence }\end{array}$ \\
\hline Nila (Oreochromis niloticus) & Purbalingga1 & 70 \\
& Purbalingga 2 & 90 \\
& Banyumas & 100 \\
& Cilacap 1 & 60 \\
& Cilacap 2 & 100 \\
\hline Gurami (Osphronemus gouramy) & Purbalingga 1 & 100 \\
& Purbalingga 2 & 100 \\
& Banyumas & 50 \\
& Cilacap 1 & 30 \\
& Cilacap 2 & 50 \\
\hline
\end{tabular}

kemungkinan sumber infeksinya berasal dari benih. Kemungkinan lain adalah sumber infeksi berasal dari ikan lain yang masuk ke dalam kolam tersebut. $\mathrm{Hal}$ ini terbukti dari ikan sampel nila yang diperoleh dari lokasi yang sama (Sleman 1) ternyata juga terinfeksi oleh mycobacteriosis yang menunjukkan prevalensi yang agak tinggi.

Aktivitas budi daya ikan di Provinsi Jawa Timur dapat dikatakan sudah cukup tinggi. Selain ikan hias, komoditas yang banyak dibudidayakan di daerah tersebut adalah ikan lele (Clarias batrachus), ikan gurami (Osphronemus gouramy), ikan mas/tombro (Cyprinus carpio), dan nila (Oreochromis niloticus). Daerah Blitar dan Tulung Agung merupakan daerah yang cukup maju dalam usaha budi daya ikan. Bahkan menurut informasi yang diperoleh bahwa kedua daerah tersebut merupakan pemasok ikan bagi
Surabaya dan Jakarta. Adapun sumber air yang digunakan baik di Blitar maupun di Tulung Agung adalah air tanah yang diangkat dengan menggunakan pompa bertenaga diesel.

Dari hasil yang diperoleh ternyata bahwa sampel ikan lele tidak terinfeksi mycobacteriosis. Ikan gurami lebih banyak dibudidayakan di daerah Malang, Blitar, dan Tulung Agung. Malang dan Blitar merupakan daerah yang memproduksi benih gurami sedangkan Tulung Agung merupakan daerah pembesar. Daerah Madiun walaupun ada budi daya ikan gurami namun tidak sebanyak yang dilakukan di daerah Blitar dan Tulung Agung. Oleh karena itu prevalensi tertinggi infeksi mycobacteriosis pada ikan gurami didapat dari kedua daerah tersebut, terutama pada sampel yang diperoleh dari Kecamatan Kanigoro dan Talun di Kabupaten Blitar dan Kecamatan Ngunut, Kabupaten

Tabel 5. Prevalensi (\%) dan spesies yang rentan terhadap infeksi mycobacteriosis pada beberapa kabupaten di Daerah Istimewa Yogyakarta

Table 5. Prevalence (\%) and the susceptable species to the infection of mycobacteriosis at some districts in Yogyakarta Province

\begin{tabular}{clc}
\hline $\begin{array}{c}\text { Jenis ikan } \\
\text { Species of fish }\end{array}$ & \multicolumn{1}{c}{$\begin{array}{c}\text { Lokasi } \\
\text { Location }\end{array}$} & $\begin{array}{c}\text { Prevalensi (\%) } \\
\text { Prevalence }\end{array}$ \\
\hline Nila (Oreochromis niloticus) & Sleman 1 & 30 \\
& Sleman 2 & 40 \\
& Bantul 1 & 0 \\
& Bantul 2 & 10 \\
\hline Gurami (Osphronemus gouramy) & Sleman 1 & 87.5 \\
& Sleman 2 & 30 \\
& Bantul 1 & 30 \\
& Bantul 2 & 37.5 \\
\hline
\end{tabular}


Tabel 6. Prevalensi (\%) dan spesies yang rentan terhadap infeksi mycobacteriosis pada beberapa kabupaten di Provinsi Jawa Timur

Table 6. Prevalence (\%) and the susceptable species to the infection of mycobacteriosis at some districts in East Java Province

\begin{tabular}{llc}
\hline $\begin{array}{c}\text { Jenis ikan } \\
\text { Species of fish }\end{array}$ & \multicolumn{1}{c}{$\begin{array}{c}\text { Lokasi } \\
\text { Location }\end{array}$} & $\begin{array}{c}\text { Prevalensi (\%) } \\
\text { Prevalence }\end{array}$ \\
\hline Nila (Oreochromis niloticus) & Malang & 15 \\
\hline Gurami (Osphronemus gouramy) & Malang & 0 \\
\cline { 2 - 3 } & Blitar 1.1 & 5 \\
& Blitar 1.2 & 0 \\
& Blitar 2 & 30 \\
& Tulung Agung 1 & 30 \\
& Tulung Agung 2 & 25 \\
& Madiun 2 & 10 \\
\hline Mas (Cyprinus carpio) & Madiun1 & 0 \\
\hline Lele (Clarias batrachus) & Malang & 0 \\
& Blitar 1 & 0 \\
& Tulung Agung & 0 \\
& Madiun1 & 0 \\
\hline
\end{tabular}

Tulung Agung. Menurut informasi yang diperoleh, penyakit yang menunjukkan gejala mata menonjol dan badan bengkak ternyata sering terjadi terutama di daerah tersebut. Bahkan ketika penelitian dilakukan di Kecamatan Ngunut pada beberapa kolam petani yang dikunjungi sedang mewabah penyakit ini.

Walaupun sumber air yang digunakan untuk budi daya ikan gurami baik di Kanigoro, Talun (Blitar), serta Ngunut (Tulung Agung) adalah air tanah, namun insidensi infeksi mycobacteriosis cukup tinggi. Sehingga jelas bahwa sumber infeksi bukan berasal dari sumber air. Khusus untuk ikan gurami yang diteliti di Kecamatan Ngunut ternyata benih dan telurnya didatangkan dari daerah Purwokerto. Oleh karena itu sumber infeksi kemungkinan berasal dari telur dan benih yang digunakan.

Secara keseluruhan dapat dikatakan bahwa jenisjenis ikan yang dapat terinfeksi oleh penyakit mycobacteriosis meliputi ikan mas (Cyprinus carpio), nila (Oreochromis niloticus), dan gurami (Osphronemus gouramy). Sedangkan ikan lele (Clarias batrachus) tidak ada indikasi dapat terinfeksi oleh mycobacteriosis.

Mycobacteriosis ternyata sudah menyebar di seluruh daerah yang disurvai di Pulau Jawa terutama di daerah-daerah sentra budi daya ikan. Data selengkapnya tentang prevalensi serta spesies yang rentan terhadap infeksi mycobacteriosis dari masingmasing daerah yang disurvai dapat dilihat pada Tabel $1,2,3,4,5$, dan 6 .
Kalau dilihat dari kecenderungan penerapan sistem budi daya misalnya Tasikmalaya, Purbalingga, dan Tulung Agung yang telah menerapkan sistem budi daya monokultur pada ikan gurami ternyata dapat dilihat bahwa prevalensi infeksi mycobacteriosis cenderung lebih tinggi.

\section{KESIMPULAN}

Dari hasil yang diperoleh dapat diambil kesimpulan sebagai berikut:

* Jasad penyebab penyakit mycobacteriosis pada beberapa spesies ikan pada lokasi yang diteliti adalah Mycobacterium fortuitum.

* Jenis-jenis ikan yang dapat terinfeksi oleh penyakit mycobacteriosis meliputi ikan mas (Cyprinus carpio), nila (Oreochromis niloticus), dan gurami (Osphronemus gouramy). Sedangkan ikan lele (Clarias batrachus) tidak ada indikasi dapat terinfeksi oleh mycobacteriosis.

« Mycobacteriosis telah menyebar ke seluruh daerah yang diteliti meliputi daerah Jawa Barat, Banten, Daerah Khusus Ibukota Jakarta, Jawa Tengah, Daerah Istimewa Yogyakarta, dan Jawa Timur.

\section{UCAPAN TERIMA KASIH}

Pada kesempatan ini perkenankanlah penulis mengucapkan banyak terima kasih kepada Kepala Dinas Perikanan dan Kelautan Provinsi Jawa Barat, 
Banten, Jawa Tengah, Daerah Istimewa Yogyakarta, dan Jawa Timur yang telah mengijinkan dan membantu kami dalam melaksanakan penelitian ini.

\section{DAFTAR PUSTAKA}

Amos, K.H. 1985. Procedures for the detection and identification of certain fish pathogen. $3^{\text {rd }}$ ed. Fish Health Section, American Fisheries Society. Corvallis, Oregon. $114 \mathrm{pp}$.

Chinabut, S., C. Limsuwan, and P. Chanratchakool. 1990. Mycobacteriosis in the snakehead (Channa striatus). J. Fish Dis. 13:531--535.

Cowan, S.T. 1985. Manual for the Identification of Medical Bacteria. Cambridge University Press. Cambridge. $238 \mathrm{pp}$.

Frerichs, G.N. 1993. Mycobacteriosis: nocardiosis. in V. Inglis, R.J. Robertsand N. Bromage (Eds.). Bacterial Diseases of Fish. Blackwell Scientific Publication. Oxford. U.K. p. 219--233.

Frerichs, G.N. and S.D. Millar. 1993. Manual for the Isolation and Identification of Fish Bacterial Pathogens. Pisces Press, Stirling 58 pp.

Limsuwan, C., S. Chinabut, K. Pawapuitanon, and $\mathrm{O}$. Lawhavinit. 1983. Tuberculosis (mycobacteriosis) in snakehead (Ophiocephalus striatus). National Inland Fisheries Institute. Technical Paper 2. Fisheries Department. Bangkok, Thailand.

Somsiri, T. and N. Sukrakanchana. 1997. Antigenic Determination of Fish Mycobacterium Strains. In T.W. Flegel and I.H. MacRae (eds.) Diseases in Asian Aquaculture III. Fish Health Section, Asian Fisheries Society, Manila p. 75--78.

Supriyadi, H. dan P. Taufik. 1981. Identifikasi dan cara penanggulangan penyakit bakterial pada ikan lele (Clarias batrachus). Bull. Perik. / (3): 447 -454.

Supriyadi, H. dan A. Rukyani. 1990. Immunopropilaksis dengan cara vaksinasi pada usaha budi daya ikan. Seminar Nasional Ke-ll, Penyakit Ikan dan Udang, Bogor, 16--18 Januari 1990. 6 pp.

Supriyadi, H. 1999. Insidensi Mycobacteriosis pada ikan gurame (Osphronemus gouramy). Makalah disampaikan pada Seminar Nasional III Penyakit Ikan dan Udang, Yogyakarta 8--9 November 1999. $5 \mathrm{pp}$.

Taufik, P. 1992. Penyakit pada ikan gurame (Osphronemus gouramy Lac.) dan penanggulangannya. Makalah pada Pertemuan Aplikasi Teknologi Budidaya Ikan Gurame, 24--26 Agustus 1992 di Yogyakarta. 5 pp. 
